\title{
Analisis Biofisik Tanaman Padi dengan Citra Drone (UAV) Menggunakan Software Agisoft Photoscan
}

\author{
Elma Irawaty ${ }^{1}$, Daniel ${ }^{1}$ dan Mahmud Achmad ${ }^{1}$ \\ Program Studi Teknik Pertanian, Universitas Hasanuddin Makassar
}

\begin{abstract}
ABSTRAK
Hasil pertanian yang sangat penting dalam kehidupan masyarakat Indonesia antara lain adalah padi. Akan tetapi, salah satu tantangan dalam membangun pertanian adalah adanya kecenderungan menurunnya produktivitas lahan. Salah satu upaya pencegahannya adalah menerapkan sehingga dapat memperoleh informasi berupa data citra penggambaran kondisi fisik tanaman (ketinggian atau kerapatan) sebagai data bantuan untuk menghitung produktivitas lahan sawah. Tujuan dari penelitian ini adalah untuk mengetahuitingkat produktivitas padiberdasarkan varietas dan pola tanam menggunakan pengolahan data citra tiga dimensi (3D). Tahapan dari penelitian ini dimulai dari pengambilan data citra dan pengukuran lapangan, kemudian data citra akan diolah menggunakan Software Agisoft Photoscan. Software Agisoft Photoscan ini memanfaatkan metode stereoskopis yang mengubah data citra 2D menjadi 3D. Pengukuran dilakukan pada beberapa sampel yang memiliki varietas dan pola tanam berbeda. Kemudian dilakukan validasi data antar kedua pengukuran agar tingkat akurasi dapat diperoleh. Selain itu, dilakukan juga pengukuran dengan menggunakan data uji yang berfungsi sebagai analisis prediksi nilai pengukuran kondisi fisik tanaman. Berdasarkan hasil pengolahan data didapatkan bahwa tingkat akurasi pengukuran menggunakan software Agisoft Photoscan untuk ketinggian tanaman mencapai $70 \%$, sedangkan kerapatan tanaman mencapai tingkat akurasi sebesar $60 \%$.
\end{abstract}

\section{Kata kunci : Padi, Stereoskopis, Kondisi Fisik,3D (tiga dimensi), software Agisoft Photoscan}

\section{PENDAHULUAN}

\section{Latar Belakang}

Indonesia merupakan salah satu negara yang memiliki lahan pertanian yang sangat luas. Selain itu, Indonesia merupakan negara agraris yang kegiatan dan hasil pertaniannya sangat berpengaruh terhadap kehidupan rakyatnya. Salah satu hasil pertanian yang merupakan aspek penting dalam kehidupan masyarakat Indonesia adalah padi. Padi merupakan kebutuhan pokok sebagian besar warga Indonesia. Padi juga merupakan sumber penghasilan terbesar bagi para petani. Karena padi merupakan hasil pertanian yang sangat berpengaruh bagi masyarakat, maka produktivitas padi perlu ditingkatkan.

Akan tetapi, salah satu tantangan dalam membangun pertanian adalah adanya kecenderungan menurunnya produkstivitas. Hal ini dapat dicegah dengan melakukan upaya dalam menjaga kelestarian tanaman padi. Agar usahatani padi dapat berkelanjutan, penerapan teknologi akan sangat berpengaruh. Teknologi yang diterapkan harus memperhatikan faktor lingkungan, baik lingkungan fisik maupun lingkungan sosial.

Salah satu pencapaian usahatani padi yang produktif adalah penerapan teknologi dalam memetakan suatu lahan. Pemetaan lahanakan membantu meningktakan produktivitas tanaman padi. Dengan adanya pemetaan lahan, informasi mengenai lahan tersebut dapat diperoleh dengan mudah, murah dan lebih akurat salah satunya kondisi fisik tanaman berupa tinggi tanaman dan kerapatan.

Maka dari itu dilakukanlah penelitian ini agar dapat menganalisis varietas tanaman padi dan pola tanamsehingga dapat mempermudah 
dalam meengetahui tingkat produktivitas berdasarkan informasi kondisi fisik tanaman berupa ketinggian tanaman maupun kerapatan yang diperoleh dari data citra UAV dengan mengubah peta 2D (data citra) menjadi peta 3D. Peta 3D yang diperoleh dapat diolah dan dianalisis menggunakan softwareAgisoft Photoscan.

\section{Tujuan dan Kegunaan}

Penelitian ini bertujuan untuk mengetahui tingkat produktivitas padi berdasarkan varietas dan pola tanam dengan mengidentifikasi kondisi fisik tanaman (tinggi tanaman dan kerapatan) menggunakan pengolahan data citra tiga dimensi (3D).

Kegunaan dari penelitian ini adalah memberikan informasi berupa peta kondisi fisik tanaman (ketinggian tanaman dan kerapatan) padi untuk mempermudah menghitung produktivitas yang dapat dihasilkan.

\section{TINJAUAN PUSTAKA}

\section{Tanaman Padi}

Padi (Oryza sativa) merupakan makanan pokok bagi sebagian besar penduduk Indonesia. Permintaan akan komoditas ini dari tahun ke tahun mengalami lonjakan sejalan dengan bertambahnya jumlah penduduk dengan laju pertumbuhan penduduk rata-rata $1,34 \%$ per tahun. Segregasi yang terjadi pada tanaman padi yang dapat terlihat secara visual adalah perbedaan fenotipe yang meliputi antara lain tinggi tanaman dan jumlah anakan. Perbedaan fenotipe dapat terlihat apabila tanaman padi yang ditanam di lahan budidaya memiliki tinggi yang tidak seragam dan jumlah anakan yang berbeda untuk tiap-tiap rumpun padi (BKPPP, 2009).

Tanaman padi dapat dibedakan berdasarkan varietasnya. Varietas tanaman padi ini banyak sekali. Semakin beragam varietas padi yang dilepas, diharapkan masyarakat pengguna dapat memilih varietas padi yang sesuai dengan kondisi spesifik lokasi dan mampu mencapai target produksi yang telah ditetapkan. Varietas padi Unggul merupakan salah satu varietas padi yang menyilangkan varietas unggul lokal. Tujuannya adalah untuk menghasilkan varietas-varietas unggulan yang terbaik. Varietas padi Unggul adalah varietas yang bisa berkali-kali ditanam dengan perlakuan yang baik. Hasil dari panen varietas ini bisa dijadikan benih kembali. Contoh dari varietas ini adalah Ciherang, Inpari, Cilosari, Diahsuci, Bestari, Inpari Sidenuk, Pandan Putri. Pada penelitian ini, varietas yang digunakan adalah varietas padi Ciliwung, Inpari 4 dan Inpari 23. (Badan Litbang Pertanian Sukamandi, 2012).

Tabel 1. Deskripsi Varietas Padi Ciliwung, Inpari 4 dan Inpari 23.

\begin{tabular}{|c|c|c|c|}
\hline Deskripsi & $\begin{array}{l}\text { Varietas } \\
\text { Ciliwung }\end{array}$ & $\begin{array}{l}\text { Varietas } \\
\text { Inpari } 4\end{array}$ & $\begin{array}{c}\text { Var } \\
\text { ieta } \\
\text { s } \\
\text { Inp } \\
\text { ari } \\
23\end{array}$ \\
\hline $\begin{array}{l}\text { Umur } \\
\text { tanaman }\end{array}$ & $\begin{array}{l}117-125 \\
\text { hari }\end{array}$ & 115 hari & $\begin{array}{l}123 \\
\text { hari }\end{array}$ \\
\hline $\begin{array}{l}\text { Bentuk } \\
\text { tanaman }\end{array}$ & Tegak & Tegak & $\begin{array}{l}\text { Teg } \\
\text { ak }\end{array}$ \\
\hline $\begin{array}{l}\text { Tinggi } \\
\text { tanaman }\end{array}$ & $\begin{array}{l}75-124 \\
\mathrm{~cm}\end{array}$ & $\begin{array}{l}75-105 \\
\mathrm{~cm}\end{array}$ & $\begin{array}{l}85- \\
112\end{array}$ \\
\hline $\begin{array}{l}\text { Anakan } \\
\text { produktif } \\
\text { Warna } \\
\text { kaki }\end{array}$ & $\begin{array}{l}18-25 \\
\text { batang } \\
\text { Hijau }\end{array}$ & $\begin{array}{l}16-28 \\
\text { batang } \\
\text { Hijau }\end{array}$ & \\
\hline $\begin{array}{l}\text { Warna } \\
\text { batang }\end{array}$ & Hijau & Hijau & \\
\hline $\begin{array}{l}\text { Warna } \\
\text { telinga } \\
\text { daun }\end{array}$ & $\begin{array}{l}\text { Tidak } \\
\text { berwarna }\end{array}$ & Hijau & \\
\hline $\begin{array}{l}\text { Warna } \\
\text { lidah daun }\end{array}$ & $\begin{array}{l}\text { Tidak } \\
\text { berwarna }\end{array}$ & Putih & \\
\hline $\begin{array}{l}\text { Muka } \\
\text { daun }\end{array}$ & Kasar & Kasar & \\
\hline $\begin{array}{l}\text { Warna } \\
\text { daun }\end{array}$ & Hijau tua & Hijau & \\
\hline Posisi & Tegak & Tegak & Teg \\
\hline $\begin{array}{l}\text { daun } \\
\text { Daun }\end{array}$ & $\begin{array}{l}\text { Miring } \\
\text { sampai }\end{array}$ & Tegak & $\mathrm{ak}$ \\
\hline
\end{tabular}




\begin{tabular}{cccc}
\hline & & & $\begin{array}{c}\text { Var } \\
\text { ieta }\end{array}$ \\
Deskripsi & Varietas & Varietas & s \\
& Ciliwung & Inpari 4 & Inp \\
& & & ari \\
& & & 23 \\
\hline
\end{tabular}

bendera tegak

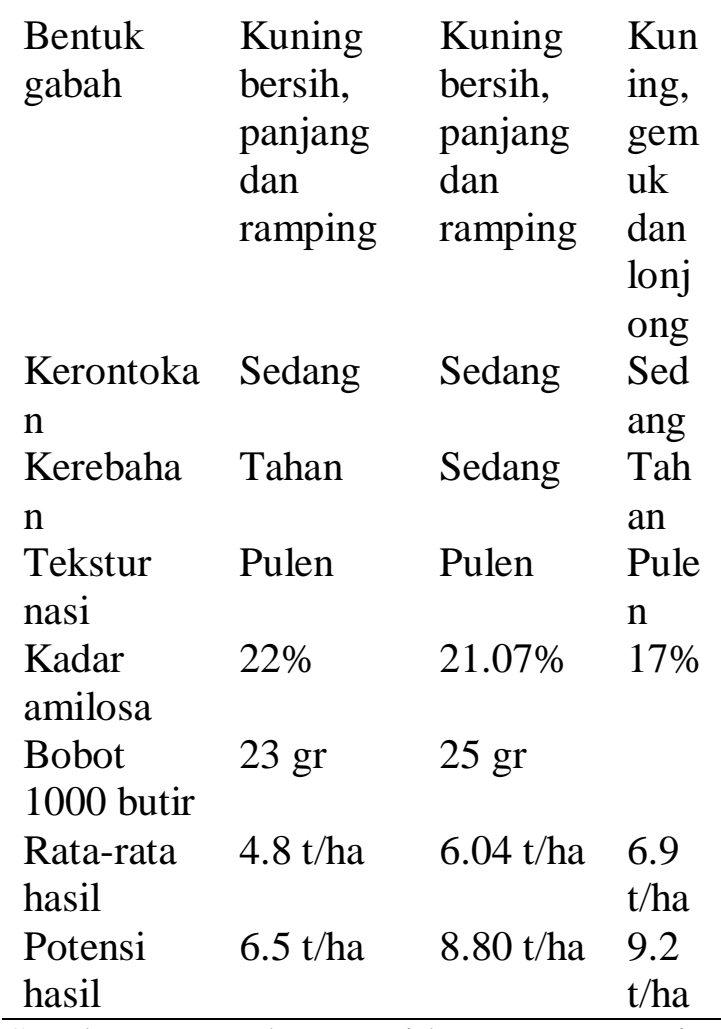

Sumber: Badan Litbang Pertanian Sukamandi, 2012.

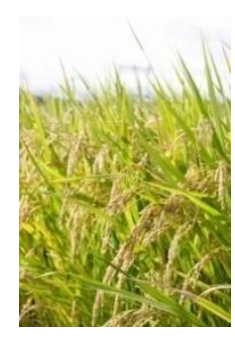

(a)

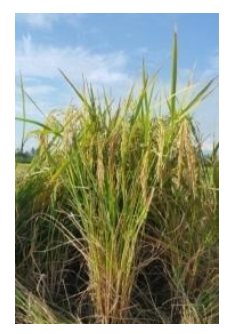

(b)

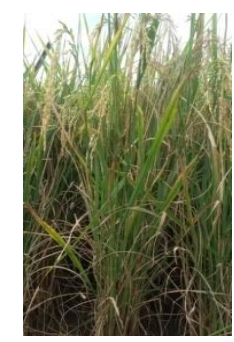

(c)
Gambar 1. Varietas Padi (a) Ciliwung, (b) Inpari 4, (c) Inpari 23.

(Sumber: Data primer, 2016).

\section{Pola Tanam Jajar Legowo dan Tegel}

Pola tanam berfungsi sebagai salah satu upaya yang dilakukan dalam menumbuhkan suatu tanaman dengan memperhatikan kebutuhan unsur hara tanaman. Pola tanam juga dapat mengatur tempat pemberian irigasi pada suatu lahan yang berpengaruh pada banyak atau tidaknya air. Menurut Badan Penelitian dan Pengembangan Pertanian (2013), beberapa macam cara atau sistem tanam padi yaitu:

a. Jajar Legowo

Sistem tanam Jajar Legowo atau disingkat Legowo memberikan lorong panjang yang lebih leluasa bagi petani melakukan pemeliharan tanpa banyak mengganggu tanaman. Oleh karena itu tanaman padi berpeluang lebih tinggi produktivitasnya apabila ditanam dengan sistem Legowo.Sistem tanam Legowo merupakan cara tanam padi sawah dengan pola beberapa barisan tanaman yang diselingi satu barisan kosong. Tanaman yang seharusnya ditanam pada barisan yang kosong dipindahkan sebagai tanaman sisipan di dalam barisan.

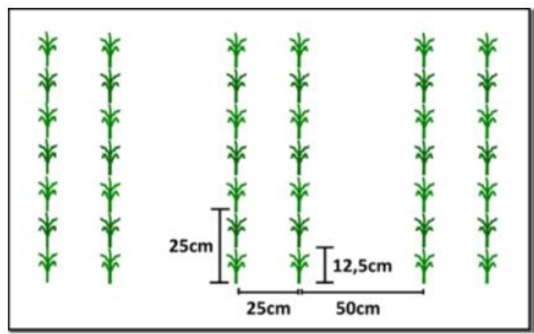

Gambar 2. Sistem Tanam Jajar Legowo (Sumber: Badan Penelitian dan Pengembangan Pertanian, 2013)

\section{b. Tegel}

Sistem tanam dengan cara ini disebut model tegel karena penempatan tanaman yang terlihat seperti susunan tegel rumah yang memiliki sisi sama seperi $25 \mathrm{x}$ $25 \mathrm{~cm}$ atau $20 \times 20 \mathrm{~cm}$. Akan tetapi para petani di Desa Alatengae menggunakan jarak tanam Tegel $28 \times 20 \mathrm{~cm}$ atau $30 \times 20$ $\mathrm{cm}$. Sistem tanam model Tegel dapat digunakan pada varietas padi yang memiliki jumlah anakan yang relatif sedikit maupun pada lahan yang kurang subur. Sistem tanam ini menghasilkan produktivitas lebih sedikit dibandingkan sistem tanam Jajar Legowo karena pada sistem tanam ini tidak diselingi ruang 
kosong yang berfungsi untuk mengurangi serangan hama yang mengganggu pertumbuhan serta mengurangi kompetisi antartanaman

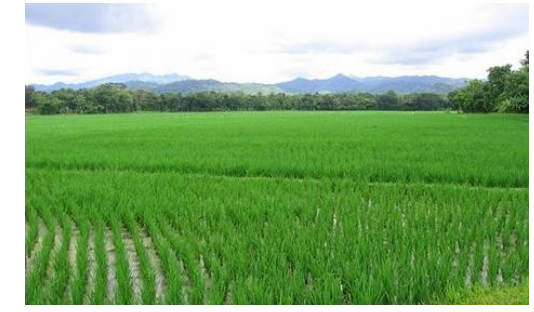

Gambar 3. Sistem Tanam Tegel

(Sumber: Badan Penelitian dan

Pengembangan Pertanian, 2013).

\section{Kondisi Fisik Tanaman}

Produktivitas suatu penanaman padi merupakan hasil akhir dari pengaruh interaksi antara faktor genetik varietas tanaman dengan lingkungan dan pengelolaan melalui suatu proses fisiologik tanaman dalam bentuk pertumbuhan tanaman. Pertumbuhan tanaman dapat dilihat dari perubahan kondi fisik tanaman yang berupa tinggi tanaman atau kerapatan tanaman (Latifah, 2004).

a. Tinggi atau Tegakan Tanaman

Pertumbuhan didefinisikan sebagai pertambahan dari jumlah dan dimensi pohon, baik diameter maupun tinggi yang terdapat pada suatu tegakan. Pertumbuhan tegakan didefinisikan sebagai perubahan ukuran dan sifat terpilih tegakan (dimensi tegakan) yang terjadi selama periode waktu tertentu, sedangkan hasil tegakan merupakan banyaknya dimensi tegakan yang dapat dipanen yang dikeluarkan pada waktu tertentu. Perbedaan antara pertumbuhan dan hasil tegakan terletak pada konsepsinya yaitu produksi biologis untuk pertumbuhan tegakan dan pemanenan untuk hasil tegakan. Pengukuran tinggi atau tegakan tanaman yaitu pengukuran jarak terpendek antara suatu titik pada puncak tertinggi tanaman (titik lain pada tanaman) dengan titik proyeksinya pada bidang datar (permukaan tanah)(Louise, 2016). b. Kerapatan Tanaman

Kerapatan tanaman merupakan salah satu faktor yang mempengaruhi pertumbuhan tanaman. Populasi dan jarak antar tanaman sangat menentukan tingginya laju pertumbuhan dan tingkat produktivitas lahan. Jumlah tanaman dan pengaturan jarak tanam di lahan harus diatur sedemikian rupa, sehingga sistem perakaran dapat memanfaatkan unsur hara tanah secara maksimal. Demikian pula kanopi tanaman sedapat Kerapatan populasi tanaman terkait dengan pemanfaatan ruang media tumbuh (Akbar, 2011).

Kerapatan rendah menyebabkan pemanfaatan sumberdaya lingkungan tidak optimal, tetapi kerapatan tinggi menyebabkan tingginya tingkat kompetisi sehingga pertumbuhan individu terhambat. Susunan daun juga jangan terlalu rapat, karena kemungkinan berpengaruh jelek pada hasil mutu yang disebabkan oleh penaungan yang berlebihan. Selain itu, kerapatan juga berhubungan dengan pola tanam pada suatu lahan (Akbar, 2011).

\section{Unmanned Aerial Vehicle (UAV)}

Teknologi pemetaan tanpa awak menjadi pilihan alternatif disamping teknologi pemetaan lainnya seperti pemotretan udara baik skala besar dan kecil berawak serta pemetaan berbasis satelit. Teknologi ini sangat menjanjikan untuk diaplikasikandikembangkan dan sesuai karakteristik topografis dan geografis Indonesia. UAV biasanya dilengkapi dengan alat atau sistem pengendali terbang melalui gelombang radio, navigasi presisi (Ground Positioning System atau GPS dan Pengukuran Inertial Unit), dan elektronik kontrol penerbangan, dan peralatan kamera resolusi tinggi. UAV dapat pula dilengkapi kamera multispektral untuk penelitian pertanian. Dalam memanfaatkan UAV untuk penelitian pertanian, data yang didapatkan berupa tampilan citra. Contoh tampilan sebuah lahan yang dimabil menggunakan UAV 
dapat dilihat pada Gambar 4 (Shofiyanti, 2011).

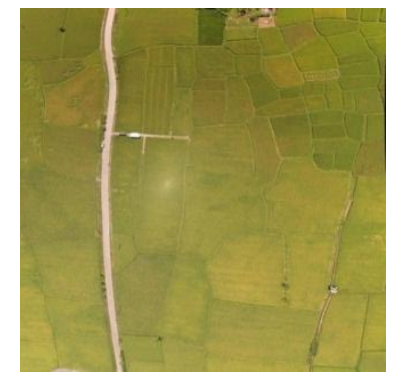

Gambar 4. Tampilan Sebuah Lahan yang diambil dari UAV dengan ketinggian 50 meter (95 HST).

(Sumber: Data primer, 2016)

\section{Stereoskopis}

Seiring dengan berjalannya waktu, perkembangan teknologi di dunia ini semakin meningkat. Teknologi yang ada sekarang ini contohnya adalah televisi dengan kemampuan menampilkan gambar 3 Dimensi (3D). Tetapi belum tentu semua orang dapat menikmati kecanggihan teknologi tersebut, dikarenakan harga televisi dengan kemampuan 3D tersebut sangatlah tinggi. Anaglyph image telah diperkenalkan sejak ratusan tahun yang lalu. Citra ini juga dikenal dengan nama stereoscopic image. Anaglyph image merupakan citra yang akan tampak lebih timbul untuk beberapa obyek sehingga tampak seperti dalam bentuk 3D. Anaglyph image dapat tampak dalam bentuk 3D karena setiap mata manusia memiliki sudut pandang yang berbeda (Ivan, 2012).

Penglihatan dengan stereoskopi memungkinkan kita untuk melihat suatu objek secara simultan dari dua perspektif yang berbeda, seperti dua foto udara yang diambil dari keududukan kamera yang berbeda, untuk memperoleh kesan mental suatu model tiga dimensi (Hadi, 2007).

\section{Software Agisoft Photoscan}

\footnotetext{
Software Agisoft PhotoScan merupakan salah satu software untuk mengolah fotogametri. Software ini dapat melakukan pengolahan fotogrametri gambar digital dan menghasilkan data spasial 3D untuk digunakan dalam aplikasi GIS, dan sebagainya. Perangkat lunak ini
}

tersedia dalam versi standar dan versi Pro, versi standarcukup untuk tugas-tugas media interaktif, sedangkan versi Prodirancanguntukauthoring konten Geog raphicInformation System (GIS). Perangkat lunak ini dikembangkanoleh sebuah perusahaan Agisoft LLC yangterletakdi St.

Petersburg di Rusia. Hal ini banyak digunakan oleh para arkeolog. Selain itu, software ini juga digunakan oleh banyak perushaan pemetaan yang menggunakan UAV. Metode pengolahan data citra yang digunakan oleh software ini adalah metode stereoskopis. Penglihatan stereoskopis memungkinkan kita untuk melihat suatu objek secara simultan dari dua perspektif yang berbeda, seperti dua foto udara yang diambil dari keududukan kamera yang berbeda, untuk memperoleh kesan mental suatu model tiga dimensiData mentah yang dapat ditambahkan dan diolah pada Agisoft Photoscan dapat berupa format TIFF, DNG, JPEG, BMP, PNG, PPM dan JPEG MPO. Pada umumnya resolusi yang diperoleh dari kamera apapun memungkinkan untuk dapat digunakan pada software ini, akan tetapi resolusi dari gambar yang diambil akan mempengaruhi akurasi hasil citra (Kiessling, 2013).

Citra 2D yang dimasukkan dalam software ini akan diolah struktur objeknya sehingga pengolahan 3D menggunakan software ini dapat dilakukan. Dalam pengolahan menggunakan software ini, parameter yang dapat diberikan adalah nilai $\mathrm{x}$, nilai $\mathrm{y}$, koordinat dunia nyata $\mathrm{z}$ dari pusat kamera proyeksi, pandangan lurus dan sudut kamera. Photoscan dapat mengikat titik secara otomatis berdasarkan pencocokan titik koordinat sehungga dapat diketahui posisi kamera pada setiap gambar sehingga posisi kamera dari gambar dapat terbentuk dan terlihat citra 3D. Pada tahap ini juga dapat dilakukan penyelarasan untuk setiap gambar agar gambar yang dihasilkan dapat digunakan pada software lain. Pada tahap dense point cloud gambar-gambar yang memiliki 
tekstur dapat dimodelkan sehingga terbentuk gambar 3D sesuai keadaan atau objek sebenarnya. Gambar 3D dapat dibentuk dari banyak point cloud yang saling bertampalan dan terdapat pada setiap gambar 2D setelah dilakukan image matching. Setelah terbentuk dense point cloud yang berbentuk titik-titik, dilanjutkan dengan tahap pembentukan mesh yang berupa garis-garis saling terhubung berdasarkan dense point cloud yang telah terbentuk (Kiessling, 2013).

\section{METODOLOGI PENELITIAN}

\section{Waktu dan Tempat}

Penelitian Pemantauan Kondisi Fisik dan Pemetaan Tanaman Padi untuk mengetahui Tingkat Produktivitas Menggunakan Data Citra Platform Unmanned Aerial Vehicle (UAV) dilaksanakan mulai pada Bulan Mei sampai Bulan Agustus 2016 bertempat di Desa Alatengae, Kecamatan Bantimurung, Kabupaten Maros.

\section{Alat dan Bahan}

Alat yang digunakan pada penelitian ini yaitu laptop, GPS, software Agisoft Photoscan,software ArcGIS, software GIS Sputnik, Citra Fotografik vertical UAV, patok, meteran tali rapiah, dan DRONE Modul DJI Phantom 2+.

Bahan yang digunakan pada penelitian ini adalah peta dasar lahan petakan sawah, sampel rumpun padi dan peta hasil panen petakan sawah.

\section{Metode Penelitian}

Penelitian ini dilakukan dengan metode stereoskopis. Langkah-langkah kerja metode penelitian ini adalah sebagai berikut:

\section{Pengalibrasian Kamera dan Orientasi Jalur Terbang}

Pengalibrasian kamera dilakukan agar dapat menentukan posisi kamera dalam mengambil data citra objek. Dimana, pengalibrasian ini dapat mengorientasi atau mengarahkan kamera sehingga memiliki jalur terbang yang teratur dengan tujuan memudahkan penganalisisan sesuai urutan jalur foto. Ketinggian kamera dalam mengambil data citra adalah 50 meter.

\section{Pengambilan Data Citra Berbagai Arah dan Pengambilan Data Lapangan}

Perekaman dan pengambilan data citra menggunakan DRONE Modul DJI Phantom 2+ dengan ketinggian tertentu. Pengambilan data citra juga dilakukan dalam berbagai arah agar mendapat gambar 2D dari banyak sisi sehingga proses dense cloud dapat dilakukan. Selain itu pengambilan data dilakukan dengan rentang waktu setiap dua minggu untuk satu kali pengambilan. Untuk pengukuran sampel di lapangan, diukur kondisi fisik sampel berupa tiga rumpun padi dalam setiap petak (jumlah keseluruhan 9 petak untuk 3 varietas) yang dirata-ratakan sehingga dapat diasumsikan bahwa data yang diukur adalah sama dalam satu petak tersebut. Sampel akan diukur kondisi fisiknya secara langsung serta pengambilan dilakukan sekitar dua minggu sekali. Nilai pengukuran yang akan diolah pada saat umur tanaman mencapai 38 HST, 66 HST dan 95 HST. Pengukuran dilakukan pada ketiga waktu tersebut karena perkembangan yang ingin dilihat adalah pada setiap bulan. Pengukuran tinggi tanaman diukur dari ujung pangkal batang yang tertanam pada tanah hingga tegakan yang paling tinggi. Berdasarkan pengukuran lapangan pada 95 HST, diklasifikasikan tinggi tanaman ke dalam tiga varietas, yaitu:
a. Inpari $23: 85 \mathrm{~cm}-89 \mathrm{~cm}$
b. Inpari $4: 81 \mathrm{~cm}-84 \mathrm{~cm}$
c. Ciliwung : $75 \mathrm{~cm}-78 \mathrm{~cm}$

Pengukuran kerapatan tanaman, diukur menggunakan meteran atau penggaris pada jarak antar rumpun tanaman padi pada beberapa pola tanam.

\section{Tahap Alignment}

Tahap ini dapat melakukan proses pencocokan citra atau penyelarasan untuk 
setiap gambar agar gambar yang dihasilkan dapat digunakan pada software lain.

\section{Tahap Membentuk Dense Point Cloud}

Pada tahap dense point cloud gambar-gambar yang memiliki tekstur dapat dimodelkan sehingga terbentuk gambar 3D sesuai keadaan atau objek sebenarnya. Gambar 3D dapat dibentuk dari banyak point cloud yang saling bertampalan dan terdapat pada setiap gambar 2D setelah dilakukan image matchingatau allignment.

\section{Tahap Analisis Objek}

Tahap ini dilakukan dengan cara memasukkan data yang berasal dari software Agisoft Photoscan ke software GIS Sputnik agar kondisi fisik yang diinginkan berupa ketinggian dapat diukur. Pada tahap ini, sebelum memasukkan data ke software GIS Sputnik terlebih dahulu dilakukan Georeferencing agar titik koordinat wilayah yang akan dianalisis sesuai dengan letak koordinat di permukaan bumi.

\section{Membandingkan Hasil Pengukuran Sampel dan Hasil Analisis dari SoftwareAgisoft Photoscan}

Setelah dilakukan analisis pada sampel yang diperoleh dari lapangan berupa rumpun padi, hasil analisis tersebut akan dibandingkan dengan hasil analisis yang dilakukan pada software. Untuk membandingkan hasil tersebut di gunakan parameter ketinggian dan kerapatan (jarak tanam) yang diperoleh dari hasil analisis software dan pengukuran sampel.

\section{Mengukur Parameter pada Petak Uji}

Setelah dilakukan perbandingan nilai pengukuran, selanjutnya dengan menggunakan software Agisoft Photoscan dilakukan pengukuran terhadap data uji pada beberapa petak sawah sebagai pembuktian bahwa software dapat mengidentifikasi varietas dengan melihat nilai hasil pengukuran yang masuk kedalam klasifikasi tinggi tanaman setiap varietas. Kemudian hasil nilai pengukuran jarak tanam akanmengidentifikasi bentuk pola tanam yang telah digunakan pada lahan sawah tersebut. Setelah diketahui nilai parameter kondisi fisik dari keduanya, produktivitas tanaman padi pada lahan sawah dapat diketahui berdasarkan kelompok varietasnya.

\section{Output}

Output penelitian ini berupa peta prediksi kondisi fisik tanaman padi yang membentuk hamparan pada kabupaten Maros.

\section{Bagan Alir Penelitian}

Penelitian ini dilakukan dengan bagan alir sebagai berikut:

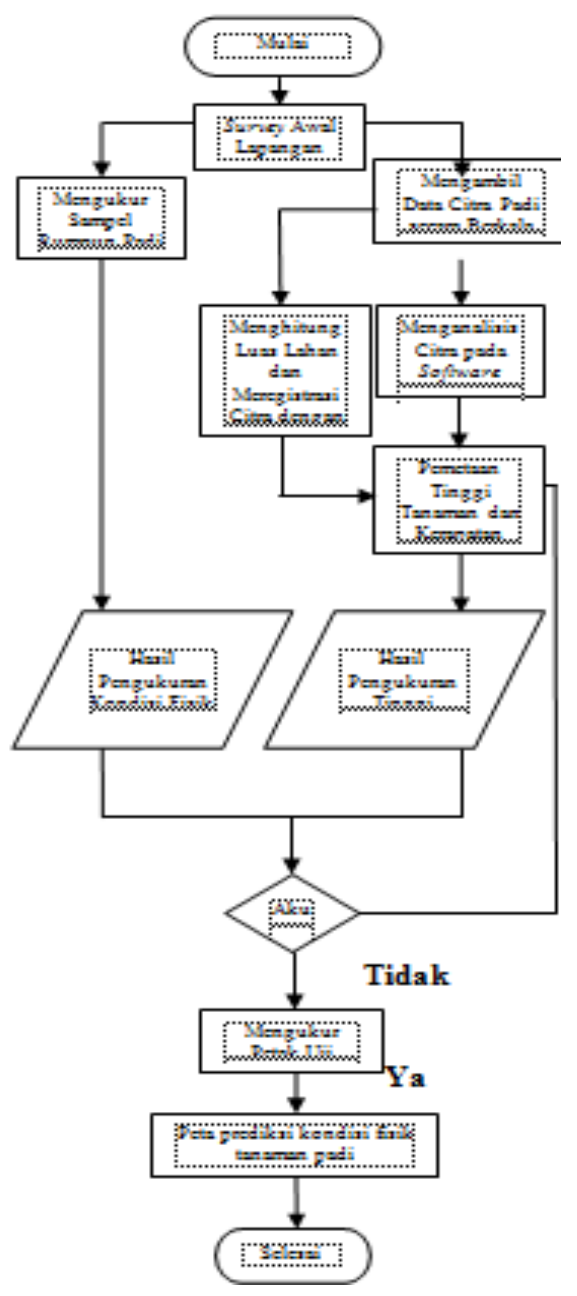

Gambar 5. Bagan Alir Penelitian 


\section{Perkembangan Biometrik Tanaman}

Berdasarkan hasil penelitian, didapatkan pengukuran lapangan mengenai ketinggian tanaman dan kerapatan tanaman padi pada bermacammacam Varietas.

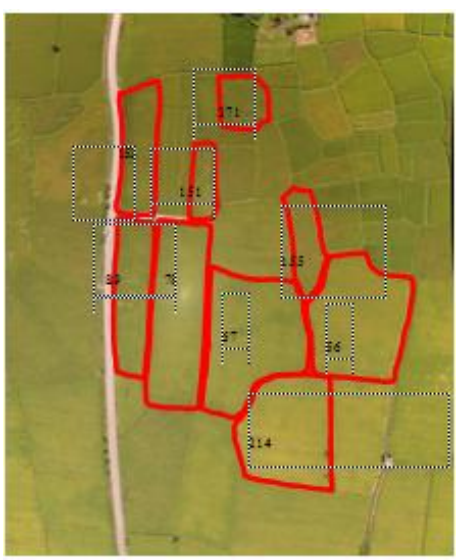

Gambar 6. Peta dasar area lahan persawahan Desa Alatengae, Kabupaten Maros

Varietas tanaman padi yang menjadi sampel untuk penelitian adalah varietas Inpari 23 pola tanam Legowo 2:1 (petak sawah 78, 89 dan 153), Inpari 23 Tegel (petak sawah 151, 153, 155), Inpari

Tabel 2. Pengukuran data lapangan kondis fisik tanaman padi berdasarkan hari setelah tanam (HST)

\begin{tabular}{|c|c|c|c|c|c|}
\hline \multirow{3}{*}{ Varietas } & \multirow{3}{*}{ Pola Tanam } & \multicolumn{4}{|c|}{ Kondisi Fisik Tanaman } \\
\hline & & \multicolumn{3}{|c|}{ Rata-rata Tinggi Tanaman (cm) } & \multirow{2}{*}{$\begin{array}{c}\text { Jarak Tanam saat } 19 \\
\text { HST }(\mathrm{cm})\end{array}$} \\
\hline & & $38 \mathrm{HST}$ & $66 \mathrm{HST}$ & $95 \mathrm{HST}$ & \\
\hline Inpari 4 & Tegel & 55.4 & 73 & 81.9 & $28 \times 20$ \\
\hline Inpari 23 & Tegel & 54.9 & 69.8 & 78 & $30 \times 20$ \\
\hline Inpari 23 & Legowo 2:1 & 59.3 & 74.4 & 86.1 & $40 \times 25 \times 20$ \\
\hline Ciliwung & Tegel & 43.7 & 65.7 & 77.1 & $25 \times 25$ \\
\hline
\end{tabular}

Tabel 2 juga menyajikan pengukuran data lapangan mengenai kondisi fisik tanaman yang berupa kerapatan tanaman. Kerapatan tanaman merupakan salah satu faktor yang dapat mempengaruhi pertumbuhan tanaman. Jarak tanam menggambarkan kerapatan tanaman terhadap tanaman lainnya. Kerapatan tanaman berhubungan dengan pola tanam yang digunakan untuk menanam benih padi. Tabel 2 menunjukkan bahwa dilakukan
4 Tegel (petak sawah 56 dan 214) dan Ciliwung Tegel (petak sawah 67) yang dapat dilihat pada Gambar 10. Tabel 2 menyajikan perkembangan kondisi fisik pada tanaman padi yaitu tinggi tanaman pada saat 38 HST, 66 HST dan 95 HST serta pengukuran jarak tanam pada umur 19 HST.

Hasil pengukuran pada Tabel 2 menunjukkan nilai tinggi tanaman yang berbanding lurus dengan umur tanaman (Hari Setelah Tanam atau HST). Hal tersebut menandakan jika tanaman padi mengalami pertumbuhan yang dilihat dengan meningkatnya jumlah tinggi tanaman. Sesuai dengan Louise (2016), yang menyatakan bahwa pertumbuhan didefinisikan sebagai pertambahan dari jumlah dan dimensi pohon, baik diameter maupun tinggi yang terdapat pada suatu tegakan. Pertumbuhan keatas (tinggi) merupakan pertumbuhan primer (initial growth), sedangkan pertumbuhan ke samping (diameter) disebut pertumbuhan sekunder (secondary growth). 
berbeda akan mempengaruhi pertumbuhan ketinggian tanaman. Pola tanam berfungsi sebagai upaya yang dilakukan dalam menumbuhkan suatu tanaman dengan memperhatikan kebutuhan unsur hara tanaman. Jika unsur hara tanaman kurang, baik karena pengaruh kompetisi antartanaman, pertumbuhan gulma akibat kelembaban yang diakibatkan oleh rapatnya jarak tanaman maupun karena pembagian unsur hara yang kurang merata pada setiap rumpun tanaman padi, maka pertumbuhan tanaman juga akan terhambat. Sesuai dengan Badan Penelitian dan Pengembangan Pertanian (2013), bahwa perbedaan metode tanam memberikan respon yang berbeda terhadap tinggi tanaman. Jarak tanam lebih rapat dan populasi lebihbanyak menyebabkan terjadinya persaingan mendapatkan cahaya matahari.

\section{Tingkat Produktivitas Padi}

Tingkat produktivitas tertinggi yang terjadi pada area persawahan Desa Alatengae, Marosndiperoleh varietas Inpari 23 yang mencapai $8.1 \mathrm{Ton} / \mathrm{Ha}$ yang disusul oleh Inpari 4 dengan 6.4 Ton/Ha dan Ciliwung yang memiliki produktivitas 6 Ton/Ha. Perbedaan tingkat produktivitas tersebut dapat dipengaruhi oleh beberapa faktor, antara lain penggunaan pola tanam, keadaan lahan dan luas lahan, kandungan unsur hara, hama dan penyakit serta keragaman varietas yang digunakan. Hal tersebut dapat dilihat pada Gambar 7.

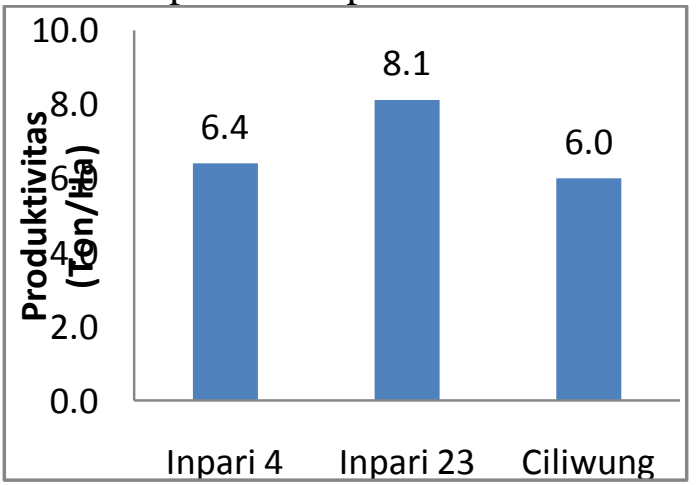

Gambar 7.Tingkat produktivitas padi tiap varietas di desa Alatengae, Maros.
Varietas Inpari 23 menggunakan pola tanam yang beragam yaitu Legowo 2:1 dan Tegel sehingga menyebabkan produktivitas lebih tinggi dibandingkan dengan Ciliwung dan Inpari 4 yang hanya menggunakan pola tanam Tegel (tingkat kerapatan tinggi). Sebagaimana diketahui bahwa penggunaan pola tanam yang memiliki kerapatan tinggi akan menghambat pertumbuhan karena kompetisi penggunaan unsur hara maupun cahaya matahari yang dibutuhkan oleh tanaman. Hal ini sesuai dengan Budi (2007), bahwa cara tanam yang padat cenderung menghasilkan ruang tumbuh tanaman yang padat pula sehingga memungkinkan terjadinya persaingan yang tinggi antar individu tanaman. Salah satu contoh adalah persaingan dalam penggunaan cahaya, dimana pada ruang tumbuh yang sempit atau jarak tanam rapat, penggunaan cahaya secara maksimum tercapai pada awal pertumbuhan. Akan tetapi, pada data Badan Litbang Pertanian Sukamandi (2012), rata-rata hasil yang diperoleh adalah 4.8 Ton/Ha untuk CIliwung, 6.04 Ton/Ha untuk Inpari 4 dan Inpari 23 mencpai 6.9 Ton/Ha. Jika dibandingkan, data tersebut lebih rendah daripada data yang diperoleh dari desa Alatengae. Hal tersebut diduga disebabkan oleh beberapa faktor lingkungan, salah satunya faktor kesesuaian varietas terhadap lahan.

Lahan yang digunakan untuk menanam keseluruhan merupakan lahan dengan tanah yang bertekstur lempung sehingga tanaman padi yang tumbuh memiliki keadaan lahan yang sama. Keberadaan unsur hara yang terdapat dalam tanah memiliki dosis yang berbedabeda dan selalu berubah-ubah sesuai dengan pemberian pupuk maupun kandungan unsur hara yang terdapat dalam tanah. Lahan persawahan tersebut diberikan takaran pupuk yang setara untuk setiap petaknya sesuai dengan luas petaknya, yaitu SP-36 $200 \mathrm{~kg} / \mathrm{Ha}$, ZA 100 $\mathrm{kg} / \mathrm{Ha}$ dan urea $125 \mathrm{~kg} / \mathrm{Ha}$.Hama dan penyakit yang menyerang tanaman padi di 
daerah persawahan desa Alatengae juga beragam antara lain, wereng, hama putih, penggerek batang dan blast. Akan tetapi, hama dan penyakit tersebut menyerang petak sawah 67 yang memiliki varietas Ciliwung. Hal tersebut diduga menjadi salah satu faktor yang menyebabkan tingkat produktivitas varietas Ciliwung lebih rendah daripada Inpari 23 dan Inpari 4.Berdasarkan hal-hal tersebut, dapat diketahui bahwa tingkat produktivitas padi dapat dipengaruhi oleh masing-masing faktor dan saling mempengaruhi satu sama lain karena tingkat produktivitas tanaman padi tidak dapat dipengaruhi oleh satu faktor saja.

\section{Pengolahan Data menggunakan Software Agisoft Photoscan}

Pengukuran estimasi ketinggian tanaman dilaukan oleh software Agisoft Photoscan dengan mengolah data citra 2D menjadi 3D. Software Agisoft Photoscan merupakan salah satu software pengolahan data citra yang mengubah data 2D menjadi data 3D. Sesuai dengan Kiessling (2013), yang menyatakanbahwa Software Agisoft PhotoScan merupakan salah satu software untuk mengolah fotogametri. Software ini dapat melakukan pengolahan fotogrametri gambar digital dan menghasilkan data spasial 3D untuk digunakan dalam aplikasi GIS, budaya dokumentasi warisan, dan produksi efek visual serta untuk pengukuran tidak langsung dari objek berbagai skala. Data citra 2D yang digunakan pada penelitian ini adalah data citra yang diambil atau direkam menggunakan Drone Modul DJI Phantom Vision 2+. Perekaman data citra dilakukan diatas lahan persawahan Desa Alatengae Kecamatan Bantimurung Kabupaten Maros.

Gambar 8 menunjukkan ketinggian tanaman dapat diukur menggunakan sebuah software Agisoft Photoscan. Metode yang digunakan oleh software ini adalah metode stereoskopis. Stereoskopis merupakan salah satu metode penggabungan data citra 2D dari posisi kamera yang berbeda saat perekaman sehingga dapat memberi penglihatan 3D pada suatu objek. Hal Ini sesuai dengan Hadi (2007), yang menyatakan bahwa penglihatan stereoskopis memungkinkan kita untuk melihat suatu objek secara simultan dari dua perspektif yang berbeda, seperti dua foto udara yang diambil dari keududukan kamera yang berbeda, untuk memperoleh kesan mental suatu model tiga dimensi. Software Agisoft Photoscan dapat mengolah beberapa citra hingga menjadi citra 3D.

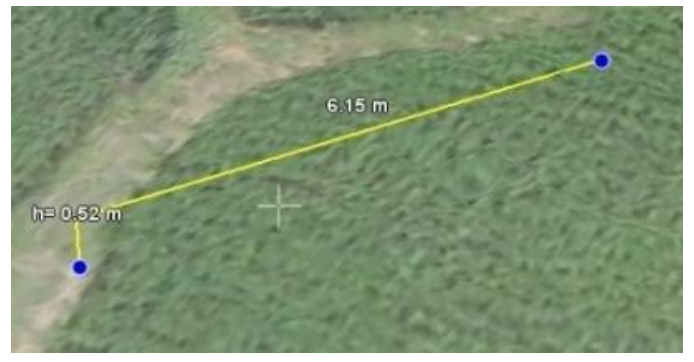

$\mathrm{a}$

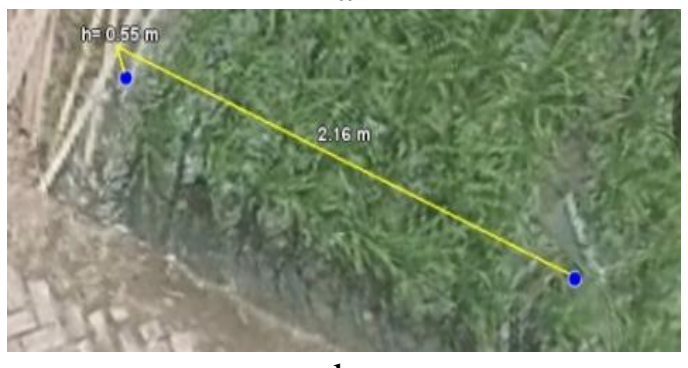

b

Gambar 8. Pengukuran Tinggi Tanaman menggunakan Software Agisoft Photoscan saat 38 HST pada: a. Petak 56 (Inpari 23 Tegel), dan b. Petak 153 (Inpari 23 Tegel).

Citra 2D memiliki titik koordinat yang berasal dari GPS pada saat merekam citra. Citra 3D terbentuk jika terjadi kecocokan antar titik koordinat dari citra itu sendiri. Titik koordinat yang saling mengikat akan menimbulkan keselarasan pada objek yang direkam sehingga terbentuk citra 3D. Sesuai dengan Kiessling (2013), yang menyatakan bahwa Photoscan dapat mengikat titik secara otomatis berdasarkan pencocokan titik koordinat sehingga membentuk citra 3D.

Gambar 9 memperlihatkan hasil pengolahan citra yang dilakukan oleh software Agisoft Photoscan pada petak 78 
(Inpari 23 Legowo 2:1), dan petak 153 (Inpari 23 Tegel). Hasil pengolahan citra tersebut berupa pengukuran ketinggian ketinggian tanaman padi pada saat 38 HST. Citra yang diolah pada software adalah citra dari petak sawah tanaman padi dengan varietas Inpari 23 dengan pola tanam Legowo 2.1 (petak sawah 78, 89, dan 153), varietas Inpari 23 dengan pola tanam Tegel (153, 155 dan 271), varietas Inpari 4 dengan pola tanam Tegel (petak sawah 56 dan 214) serta varietas Ciliwung dengan pola tanam Tegel (petak sawah 67). Hasil dari pengolahan citra tersebut dapat disajikan pada Gambar 9a dan 7b.

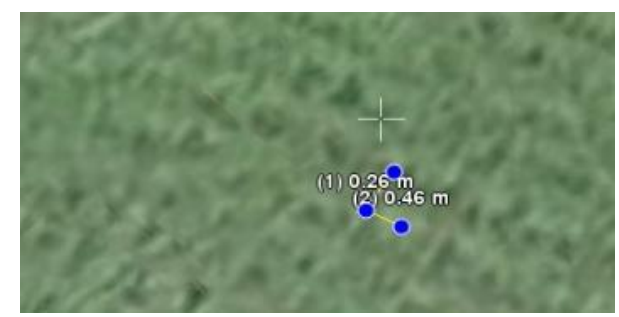

a

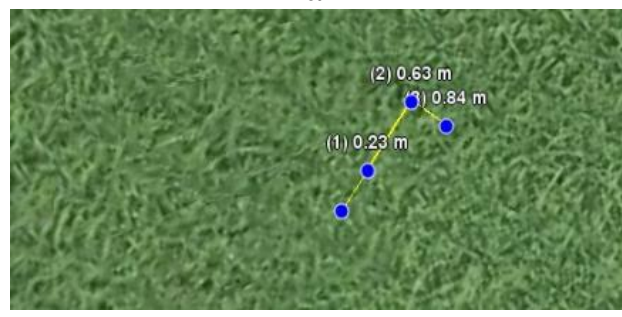

b

Gambar 9. Pengukuran Jarak Tanam menggunakan Software Agisoft Photoscan saat 19 HST pada: a. Petak 78 (pola tanam Legowo 2:1), dan b. Petak 56 (pola tanam Tegel).

Selain pengukuran tinggi tanaman, software Agisoft Photoscan juga dapat mengukur jarak. Pengukuran jarak tanam menggunakan software Agisoft Photoscan dapat dilihat pada Gambar 9. Software Agisoft Photoscan mengukur jarak dengan menggabungkan titik-titik pengukuran yang ingin diukur dengan mengakumulasikan nilai dari titik awal pengukuran hingga titik akhir pengukuran. Seperti yang terlihat pada Gambar 8a yang menunjukkan pengukuran jarak tanam pada petak 78 yang memiliki Varietas Inpari 23 dengan pola tanam Legowo 2:1 dimana terdapat 4 titik yang mengakumulasikan nilai pengukuran. Artinya, titik pertama merupakan titik awal, sedangkan ketiga titik lainnya (titik 1, 2 dan 3) masingmasing adalah jarak kolom antartanaman, jarak baris kosong dan jarak baris antartanaman. Kemudian pada Gambar 8b menunjukkan bahwa dilakukan pengukuran jarak tanam yang membentuk pola tanam Tegel pada petak 56 dengan varietas Inpari 4.

\section{Perbandingan Tinggi Tanaman dan Kerapatan Tanaman pada Nilai Pengukuran dan Nilai Estimasi}

Gambar $\quad 10$ menunjukkan perbandingan antara tinggi tanaman pengukuran dengan tinggi tanaman estimasi menggunakan software Agisoft Photoscan. Pengukuran tinggi tanaman pada saat umur tanaman mencapai 38 HST, 66 HST dan 95 HST dilakukan karena perkembangan tinggi tanaman akan dipantau pada setiap bulan.

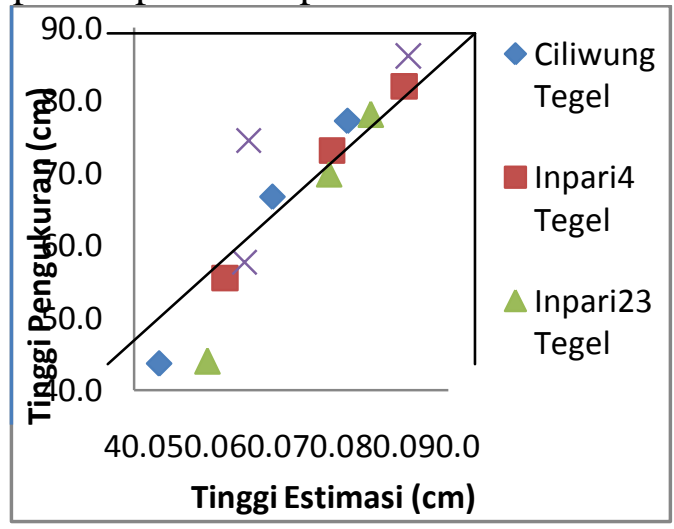

Gambar 10. PerbandinganTinggi Tanaman pada Nilai Pengukuran dan Nilai Estimasi (38 HST, 66 HST, dan 95 HST)

Berdasarkan Gambar 10, dapat dilihat bahwa terdapat grafik linear terhadap perkembangan ketinggian tanaman padi pada tinggi pengukuran dan tinggi estimasi yang artinya pada sertiap waktu HST (38 HST, 66 HST dan 95 HST) mengalami pertumbuhan. Pada Gambar 10 seluruh varietas diplotkan hingga membentuk garis-garis tersebut 
Akan tetapi, jika dilihat pada varietas Inpari 23, terdapat salah satu titik yang sedikit menajuh dari garis linearnya. Hal ini dapat dikatakan bahwa titik pengukuran tersebut dipengaruhi oleh faktor kecepatan angin yang tinggi sehingga menyebabkan daun padi yang relatif telah tinggi dan melengkung tertiup oleh angin sehingga menghalangi titik pengukuran yang akan diamati. Hal tersebut diperkuat dengan adanya data yang mengalami kesalahan terdapat pada saat umur padi 95 HST sedangkan pada saat umur 38 HST dan 66 HST hasil pengukuran lebih akurat. Kemungkinan kesalahan tersebut terjadi pada petak 89 dengan varietas Inpari 23 pola tanam Legowo 2:1 yang memiliki nilai pengukuran $85.5 \mathrm{~cm}$ sedangkan pada software memiliki nilai $45 \mathrm{~cm}$.

Selain itu perbandingan nilai kondisi fisik tanaman juga dilakukan pada pengukuran kerapatan tanaman yang berupa jarak tanamdengan menggunakan diagram batang yang dapat dilihat pada Gambar 11a dan 11b. Jarak tanam yang diukur juga dilakukan pada 9 sampel dengan tiga varietas berbeda dan dua pola tanam berbeda.
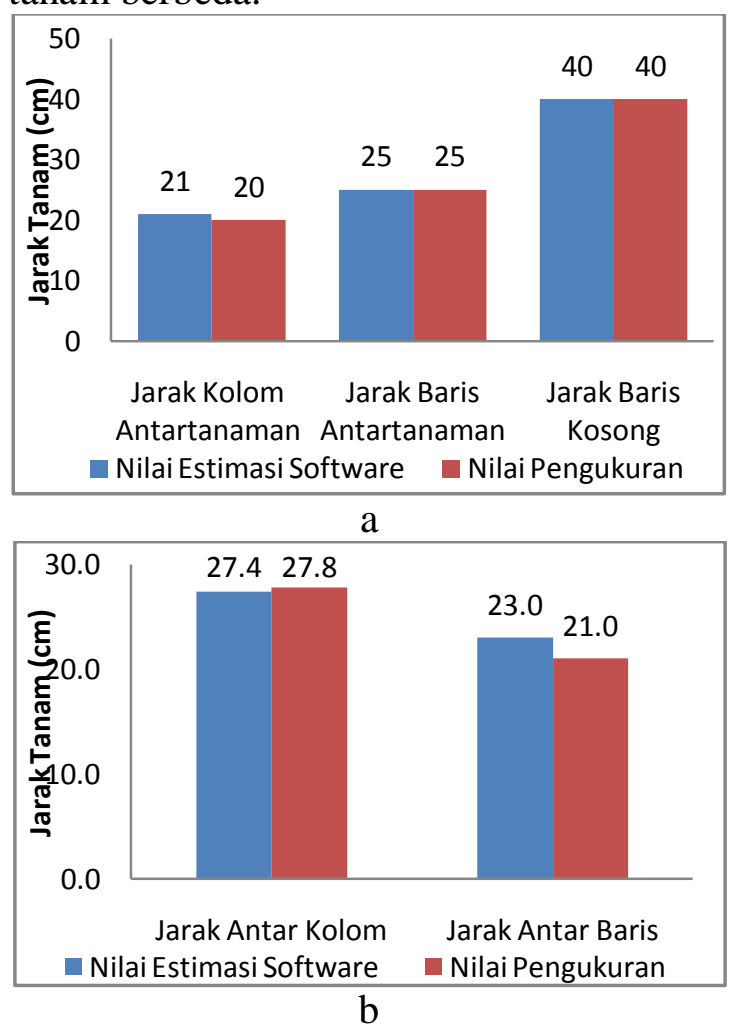

Gambar 11. Perbandingan Jarak Tanam: a. Legowo 2:1 dan b. Tegel pada Nilai Pengukuran dan Nilai Estimasi (19 HST)

Pengukuran jarak tanam ini dilakukan pada saat umur tanaman mencapai 19 HST. Pengukuran dilakukan pada waktu tersebut agar dapat mengurangi kesalahan pada saat pengolahan citra karena pada waktu tersebut daun yang muncul dari batang tanaman belum terlalu panjang dan melengkung sehingga pada saat mengambil citra daun yang melengkung tidak menutupi jarak karena daun tersebut akan menghalangi titik yang ingin diukur. Sama halnya dengan pengukuran tinggi tanaman, pegukuran jarak tanam juga dilakukan menggunakan software Agisoft Photoscan. Dilihat dari Gambar 11, terdapat nilai yang berbeda antara nilai jarak kolom antartanamanpada pengukruan jarak tanam Legowo 2:1 dan Tegel. Hal ini disebabkan karena pada saat pengambilan citra di titik tersebut, kemungkinan terdapat objek berupa daun yang melengkung sehingga menutupi jarak antar titik yang akan diukur.

\section{Estimasi Pengukuran pada Petak Uji}

Setelah dilakukan pengukuran menggunakan software pada petak sampel, dilakukan juga pengukuran pada petak uji. Petak uji merupakan petak yang ingin diujikan menggunakan software Agisoft Photoscan sehingga dapat dibuktikan bahwa nilai pengukuran yang didapatkan sesuai dengan petak sampel sehingga dari pengukuran tersebut dapat diidentifikasi varietas (dari tinggi tanaman) maupun pola tanamnya (dari kerapatan tanaman). 


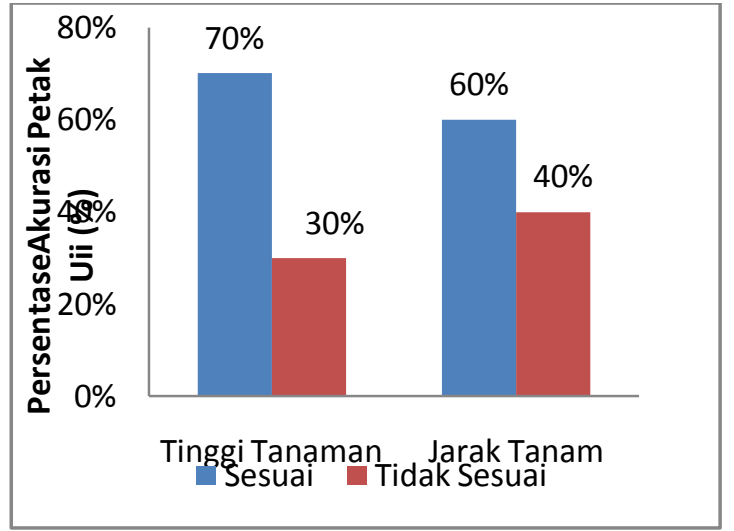

Gambar 12. Persentase Akurasi Petak Uji

Gambar 12 menunjukkan persentase hasil akurasi yang dilakukan pada beberapa petak uji. Pengukuran data pada petak uji dilakukan pada beberapa petak sawah yang bukan merupakan petak sampel. Petak sawah tersebut terdiri atas beberapa varietas (Inpari 23, Inpari 4 dan Ciliwung) serta pola tanam (Legowo 2:1 dan Tegel). Hal tersebut dilakukan agar dapat dilihat tingkat akurasi yang dihasilkan jika pengukuran dilakukan oleh software Agisoft Photoscan. Berdasarkan Gambar 12, dapat dilihat bahwa persentase akurasi untuk mengukur tinggi tanaman mencapai $70 \%$ yang sesuai dan $30 \%$ yang tidak sesuai. Artinya, nilai-nilai pengukuran yang diukur pada petak uji memiliki kesesuaian mencapai $70 \%$. Kesesuaian tersebut diperoleh dari ratarata pengukuran untuk setiap varietas dan diklasifikasikan menurut interval ketinggian tanaman, sehingga dapat dilihat nilai yang sesuai dengan hasil klasifikasi.

Kemudian Gambar 12 juga menunjukkan bahwa persentase akurasi petak uji mencapai $60 \%$ untuk pengukuran jarak tanam (kerapatan tanaman). Nilai tersebut juga diperoleh dari rata-rata nilai pengukuran jarak tanam pada software dan divalidasi menggunakan data lapangan. Kemudian dilakukan perhitungan selisih antara nilai keduanya dan diperoleh nilai persentase sebesar $60 \%$.

\section{Peta Prediksi Kondisi Fisik Tanaman Padi}

Petak lahan sawah yang dijadikan lahan penelitian ini adalah petak 78, 89, dan 153 untuk Varietas Inpari 23 pola tanam Legowo 2:1, petak 151, 155 dan 271 untuk Varietas Inpari 23 pola tanam Tegel, petak 56 dan 214 untuk varietas Inpari 4 pola tanam Tegel dan petak 67 untuk Varietas Ciliwung pola tanam Tegel.

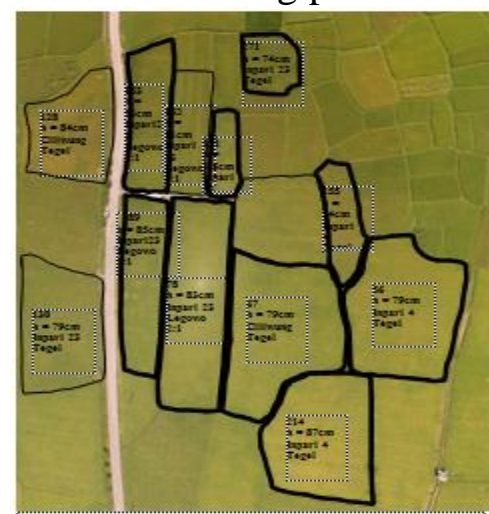

Gambar 13. Peta Prediksi Kondisi Fisik Tanaman Padi

Gambar 13 memperlihatkan peta prediksi kondisi fisik tanaman berdasarkan pengolahan software Agisoft Photoscan yang menampilkan citra 3D. Peta prediksi kondisi tanaman pada Gambar 13 diperoleh berdasarkan hasil pengukuran yang dilakukan pada beberapa petak uji menggunakan software Agisoft Photoscan. Dapat dilihat pada gambar tersebut, ketinggian tanaman yang diperoleh menggambarkan varietas dari tanaman padi. Sedangkan jarak tanam dapat menggambarkan pola tanam yang digunakan pada lahan tersebut.

Peta prediksi kondisi fisik tanaman padi pada Gambar 13 dapat digunakan sebagai informasi kondisi fisik tanaman (ketinggian tanaman dan kerapatan) sehingga data tersebut dapat mempermudah untuk menghitung prdoduktivitas yang dapat dihasilkan berdasarkan varietas dan pola tanamnya.

\section{KESIMPULAN DAN SARAN}

\section{Kesimpulan}

Software Agisoft Photoscan dapat digunakan untuk mengolah data citra 2D menjadi 3D sehingga kondisi fisik tanaman dapat diukur dengan tingkat akurasi $70 \%$ untuk ketinggian tanaman dan 
$60 \%$ untuk jarak tanam (kerapatan tanaman).

Tingkat produktivitas padi dipengaruhi oleh varietas dan pola tanam serta dapat diprediksi dengan pengukuran tinggi tanaman masksimum berdasarkan varietas dan jarak tanam yang dipantau dengan UAV dan diolah menggunakan software Agisoft Photoscan.

\section{Saran}

Sebaiknya pengambilan citra yang akan diolah menggunakan software Agisoft Photoscan dilakukan pengontrolan kecepatan angin sehingga tingkat kecepatan angin tidak mempengaruhi titik pengukuran yang akan diamati.

\section{DAFTAR PUSTAKA}

Akbar, Bari. Mukhammad M. Febri H. 2011. Pengaruh Kerapatan Terhadap Pertumbuhan dan Produktivitas Tanaman Tembakau (Nicotiana tabacum) Varietas Serumpung Dan Semboja. Institut Teknologi Sepuluh September : Surabaya.

Badan Ketahanan Pangan dan Penyuluh Pertanian Aceh. 2009. Budidaya Tanaman Padi. Sumatera Utara: Aceh.

Badan Litbang Pertanian Sukamandi. 2012. Agroinovasi: Varietas Padi Unggulan. Jawa Barat: Bandung.

Badan Penelitian dan Pengembangan Pertanian. 2013. Sistem Tanam. Jawa Barat: Bandung.

Hadi, Bambang Saiful. 2007. Dasar-dasar Fotogrametri. Universitas Negeri Yogyakarta: Yogyakarta.

Ivan, Michael. W. Gazali. N. Imanuel. 2012. Aplikasi Perubahan Citra 2D Menjadi 3D dengan Metode Stereoscopic Anaglyph berbasiskan Komputer. Universitas Bin Nusantara: Jakarta.
Kiessling, Karsten. 2013. Getting started with Agisoft PhotoScan. St. Petersburg: Rusia.

Latifah, Siti. 2004. Pertumbuhan Dan Hasil Tegakan Eucalyptus grandis di Hutan Tanaman Industri. Universitas Sumatera Utara: Medan.

Louise, A. B. 2016. Evaluasi Pertumbuhan dan Produksi Tanaman: Pengukuran Tinggi dan Panjang Tanaman. Universitas Jendral Soedirman: Purwokerto.

Shofiyanti, Rizatus. 2011.Teknologi Pesawat Tanpa Awak untuk Pemetaan dan Pemantauan Tanaman dan Lahan Pertanian. Bogor. 